\title{
Magt og vidensproduktion
}

Yvonne Mørck introducerer Patti Lather

\section{FORSKERINTRODUKTION}

\section{Patti Lather beskaftiger sig med relationen mellem køn, magt og vi- den $i$ spandingsfeltet mellem femini- stiske og postmoderne perspektiver. Resultatet er nytankning inden for teoretiske og metodologiske reflek- sioner og etik.}

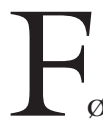

ørste gang jeg hørte om Patti Lather var, da jeg for nogle år siden deltog i et forskerkursus om kvalitative metoder hos Steinar Kvale på Center for Kvalitativ Metodeudvikling på Psykologisk Institut, Århus Universitet. Kvale havde hørt og læst denne Lather, og han mente, at hun (og i det hele taget feministiske forskere) var én af de bedste til henholdsvis at forklare og operationalisere postpositivismens og postmodernismens metodiske konsekvenser. Da jeg efterfølgende har haft mulighed for ikke blot at læse Lathers arbejder, men også at opleve hende undervise, er jeg helt enig i Kvales vurdering.

Lathers faglige baggrund er inden for "education", hvilket i en dansk sammenhæng svarer til pædagogik. Denne har hun koblet med feministisk teori, kritisk teori, en etnografisk tilgang samt et stort videnskabsteoretisk overblik, og det er blevet til en yderst spændende og lærerig cocktail. Hun er professor ved Ohio State University, hvor hun er tilknyttet "Department of 
Educational Policy and Leadership". Lather underviser i kvalitative metoder inden for uddannelse og feministisk pædagogik, og i løbet af 1990'erne er hun blevet et kendt navn inden for disse områder.

Lather forsker ikke blot i pædagogik; hun praktiserer den selv i en fornem udgave. De gange, jeg har oplevet hendes (metode)undervisning, har hun udvist en yderst pædagogisk undervisningsstil, som gav et godt indblik i, at de videnskabsteoretiske forståelser, der ligger til grund for forskellige kvalitative metoder, har konsekvenser for både resultatet og for de mennesker, der forskes i.

\section{GETTING SMART OG}

\section{Troubling the ANGels}

Lather har skrevet to bøger og adskillige artikler. I det følgende vil jeg præsentere nogle af Lathers hovedinteresser og -pointer gennem de to bøger. Hendes første bog hed Getting Smart: Feminist Research and Pedagogy with/in the Postmodern. Sammen med psykologen Chris Smithies har Lather skrevet Troubling the Angels: Women Living with $H I V / A I D S$.

Lather er interesseret $i$, hvordan magt er relateret til viden(sproduktion), og i Getting Smart forsøger hun at udvikle en model, som både kan producere emancipatorisk viden og give de mennesker, der studeres, magt. Hvordan kan en "empowering" tilgang til at generere viden på se ud? Hvordan kan man demokratisere forskningsprocessen, således at forhandling og reciprocitet kan komme i fokus? I stedet for at påtage sig rollen som den universelle talskvinde/mand skal forskeren ifølge Lather udvikle sig til en slags kulturarbejder, hvis pligt det er at tillade alle at tale på egne vegne. Forskeren skal også forholde sig til studiesubjekternes ønsker og behov ved at fokusere på, hvordan de forstår deres egen situation. En sådan forskningstilgang forsøger således at bidrage til menneskers selvforståelse og selvbestemmelse. For iføl- ge Lather (jvf. hendes feministiske rødder) har emancipatorisk forskning store implikationer for kvinder og alle andre mennesker, der er involveret i ulige magtrelationer.

Til sin teoretiske argumentation kombinerer Lather tre forskellige kritiske diskurser, nemlig feminismer, neo-marxismer og poststrukturalismer (gennem flertalsbeskrivelser påpeger hun, at der inden for hver diskurs er variationer og modsætninger). Som empirisk illustration af teoretiske pointer anvender Lather sin egen pædagogiske praksis, idet hun analyserer de erfaringer hun og hendes studerende har haft på et kursus i kvindestudier. Lather er således selvrefleksiv vedrørende egen praksis og ved at inddrage både teori og praksis præsenterer hun en ny pædagogikteori samtidig med, at hun analyserer, hvordan en sådan teori kan anvendes i praksis både på underviser- og elevsiden.

Getting Smart handler dermed om, hvordan man kan udføre samfundsvidenskabelig forskning i en postmoderne tidsalder. Lather beskriver sin egen positionering som “...shifts from 'post-Marxist feminist' to 'postmodern materialist-feminist"' (xix). Skønt hun har et ambivalent forhold til det postmoderne/-strukturalistiske projekt, forsøger hun at anvende denne "isme" konstruktivt snarere end at være angst for dens relativisme. Denne position indebærer også, at Lather er optaget af, hvordan man kan "skrive postmoderne". Dette indebærer, at man på en og samme tid anvender og problematiserer en diskurs, både udfordrer og indskriver sig i dominerende betydningssystemer på måder, således at man konstruerer egne positionerede kategorier og forståelsesrammer. Det overordnede projekt, mener Lather, består $\mathrm{i}$ at finde måder at kommunikere disse dekonstruktive ideer på, så de kan opløse både hegemoniske relationer og eksisterende forestillinger om emancipatorisk arbejde.

Disse væsentlige refleksioner om repræsentation viderefører Lather - sammen med sin medforfatter Chris Smithies - i Troub- 
ling the Angels. Hovedpersonerne i bogen er 25 hiv-smittede og aids-syge kvinder i støttegrupper i staten Ohio, som Smithies har arbejdet med igennem flere år. De to forskere foretog gruppeinterviews med kvinderne i 1992-93 samtidigt med, at de
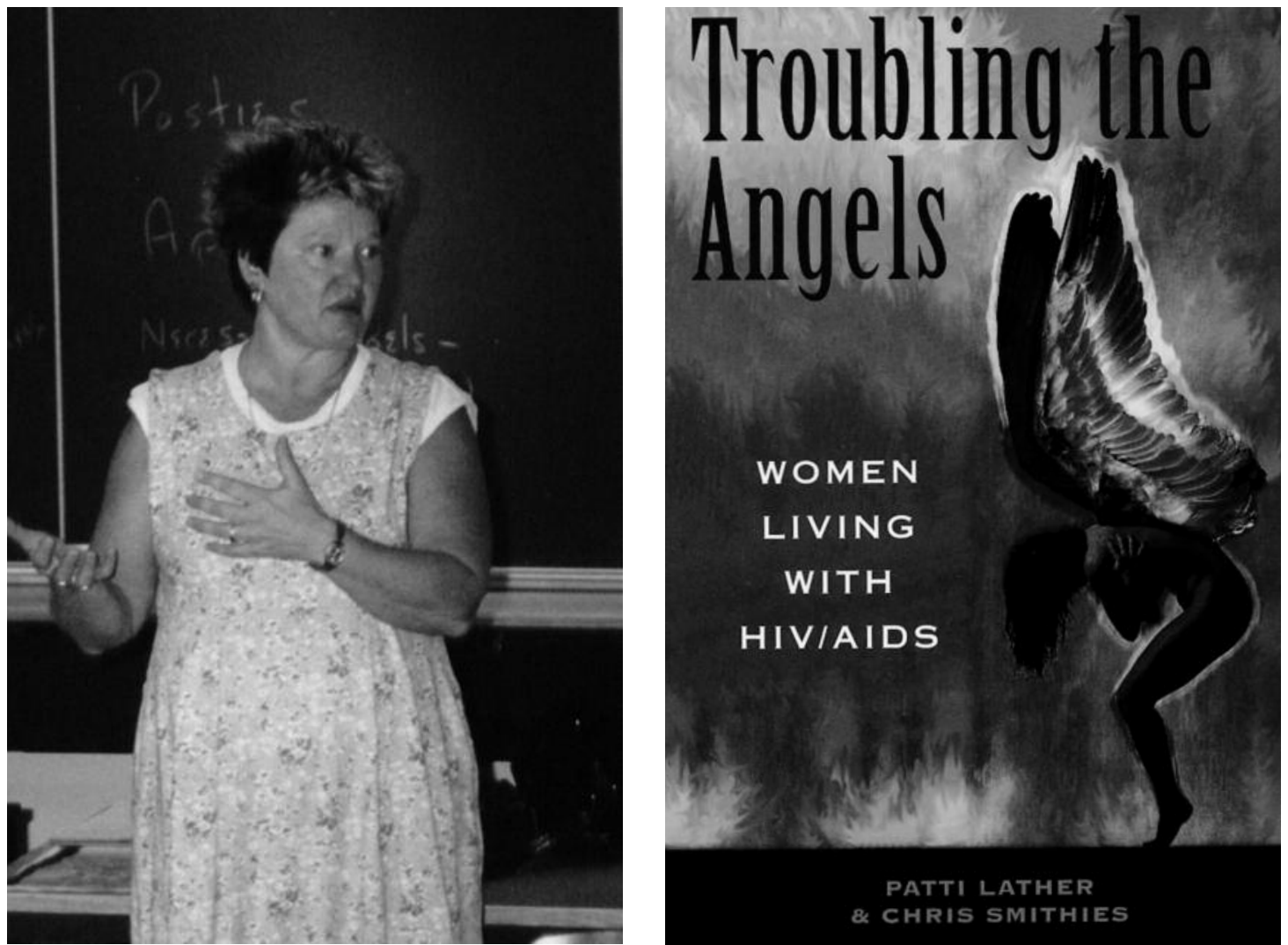

Foto: Susanne V. Knudsen

levede med i kvindernes liv i den forstand, at de deltog i deres ferier, fødselsdage, udflugter, hospitalsophold, begravelser mv. I efteråret 1994 mødtes de med nogle af kvinderne for at diskutere bogens form. Et væsentligt spørgsmål var nemlig, hvordan kunne de som feministiske forskere fă op- fyldt deres ambition om, at studiesubjekterne, dvs. kvinderne, skulle indgå som medforskere? Og hvordan skulle de mange følelser og flertydigheder i disse stigmatiserede kvinders liv fremstilles? Hvordan skulle Lathers og Smithies metodologiske refleksi- oner og projektets faktuelle proces indgå? Hvordan skulle hiv og aidssygdommen kontekstualiseres? I vinteren 1994 udtrykte nogle af kvinderne deres utålmodighed og spurgte, "Hvornår kommer den bog? Nogle af os har en deadline, som I ved!" De mente med andre ord, at de gerne ville se 
bogen færdig, før de døde, så derfor besluttede Lather og Smithies at udgive bogen $\mathrm{i}$ en forløbig udgave i desktop-form. I bogens endelige udgivelse (1997) indgår kvindernes reaktioner på denne tidlige udgave såvel som en opdatering af kvinders situation og deres støttegrupper.

Troubling the Angels er blevet en meget god illustration af, hvordan man som feministisk forsker kan representere sine informanters historier og liv i en postpositivistisk og metodisk kaotisk periode. Bogen indledes med to forord, nemlig forst en introduktion af bogen og derefter af kvinderne, hvor flere af kvinderne selv kommer til orde. Bogens kerne består af fem hovedsektioner, der indeholder kvindernes erfaringer og beretninger om temaerne "Life after Diagnosis", "Relationships", "Making Meaning", "Living/Dying with Aids" og "Support Groups". Hver af de fem dele afsluttes med en såkaldt "Intertext", hvor forfatterne kontekstualiserer de sociale og kulturelle sider af hiv og aids bl.a. gennem englemetaforen. Disse overordnede tekster fungerer som både broer mellem og pusterum fra kvindernes historier. I det meste af bogen er der en bundtekst, hvor Lather og Smithies kommenterer og reflekterer over forskningsmetoder, videnskabsteoretiske rammer og deres erfaringer med at skrive bogen sammen. Rundt i hele bogen er der eksempler på kvindernes egne skrifter i form af breve, digte og taler samt "faktuelle kasser", hvor læseren oplyses om udbredelsen af hiv og aids mv.

Lather og Smithies har således bevidst skabt en "rodet tekst", idet de ikke har fundet en anden mere passende form at præsentere kvinders liv i. Denne form indebærer bl.a., at forfatterne er til stede i teksten, og at de tillader sig at være uenige både med nogle af kvinderne, f.eks. om fortolkningen af sygdommen og med hinanden. Deres intention med bogen, nemlig "...rather than only 'giving voice' to the stories of others, this is also a book about researchers both getting out of the way and getting in the way" og "...this book, then, is about the limits of what can be said and known about the lives of others" (xiv) er til fulde opfyldt. Det lykkes således at holde balancen mellem empati, autenticitetsfælden, romantiseringen af at lade usynliggjorte og stigmatiserede mennesker komme til orde og forskerbekendelser, hvorved bogen rammer midt ned i debatten om den feministiske forsknings etiske og politiske implikationer.

Lather har efterfølgende arbejdet med, hvad hun betegner sit "postbook project", dvs. hun reflekterer over de teoretiske og metodologiske erfaringer fra Troubling the Angels på et mere abstrakt og alment niveau. Med denne forskning forsætter hun sin metodiske nytænkning, som er til stor gavn for alle, der er interesseret i kvalitativt orienteret forskning og dens fremtid. Alle med interesse for videnskabsteoretiske problemstillinger, feministisk teori og pædagogik samt metoderefleksioner kan anbefales at stifte bekendtskab med Lathers forfatterskab. Der er megen viden og inspiration at hente, idet hun på levende vis formår at kombinere epistemologi med metode, så det bliver til en yderst anvendelig metodologi.

\section{LITTERATUROVERSIGT}

\section{BØGER}

- Lather, Patti (1991): Getting Smart. Feminist Research and Pedagogy with/in the Postmodern. Routledge, New York.

- Lather, Patti \& Smithies, Chris (1997): Troubling the Angels. Women Living with HIV/AIDS. Westview Press, Boulder.

\section{ARTIKLER}

- Lather, Patti (1984): Critical theory, curricular transformation and feminist mainstreaming, in Journal of Education, 66 (1), pp. 49-62.

- Lather, Patti (1986a): Research as praxis, in Harvard Educational Review, 56 (3), pp. 257277. 
- Lather, Patti (1986b): Issues of validity in openly ideological research: Between a rock and a soft place, in Interchange, 17 (4), pp. 63-84.

- Lather, Patti (1987): Patriarchy, capitalism and the nature of teacher work, in Teacher Education Quarterly, 14 (2), pp. 25-38.

- Lather, Patti (1988): Feminist Perspectives on empowering research methodologies, in Women's Studies International Forum, 11 (6), pp. 569-581. - Lather, Patti (1989): Postmodernism and the politics of enlightenment, in Educational Foundations, 3 (3), pp. 7-28.

- Lather, Patti (1992a): Critical frames in educational research. Feminist and poststructural perspectives, in Theory Into Practice, 31 (2), pp. 2-13 (theme issue: Qualitative issues in educational research).

- Lather, Patti (1992b): Postmodernism and the human science, in Kvale, S. (ed.): Psychology and postmodernism. Sage, London. pp. 88-109.

- Lather, Patti (1993): Fertile obsession: Validity after poststructuralism, in The Sociological Quarter$l y, 34$, pp. 673-693.

- Lather, Patti (1994a): Critical Inquiry in Qualita- tive Research. Feminist and Post-structural perspectives: Science "after truth", in Chabree, B. et al. (eds): Exploring Collaborative Research in Primary Care. Sage, London. pp. 103-114.

- Lather, Patti (1994b): Staying dumb? Feminist research and pedagogy with/in the postmodern, in Simins, H.W. \& Billig, M. (eds.): After postmodernism: Reconstructing ideology critique. Sage, London, pp. 101-132.

- Lather, Patti (1995): The validity of angels: Interpretive and textual strategies in researching the lives of women with HIV/AIDS, in Qualitative Inquiry, l (1), pp. 219-228.

- Lather, Patti (1996): Troubling clarity: The politics of accessible language, in Harvard Educational Review, 66 (3), pp. 525-545.

- Lather, Patti (1997): Drawing the line at angels: Working the ruins of feminist ethnography, in Qualitative Studies in Education, 10 (3), pp. 285304.

Yvonne Mørck, ph.d., mag.scient., adjunkt ved Sociologisk Institut, Københavns Universitet 